\title{
Disclosures On:
}

New Syntheses of Perfluorostyrene and Other Highly Fluorinated Derivatives

Temperature-, Radiation-, and Vacuum-Resistant Magnetic Tape

Conductometric Titration Cell

Mill Work Positioner

U.S. PARTMENT

OF COMMERCE

National

Direau

QC of

100 rds

5753

0.744

Process for Fabricating Superconducting Microbridges Apparatus for Displaying Average Wind Vane or Other Shaft Position

Document Numbering Machine Responsive to a Staple in a Print Area for Printing in an Alternate Area 
The National Bureau of Standards ${ }^{1}$ was established by an act of Congress March 3, 1901. The Bureau's overall goal is to strengthen and advance the Nation's science and technology and facilitate their effective application for public benefit. To this end, the Bureau conducts research and provides: (1) a basis for the Nation's physical measurement system, (2) scientific and technological services for industry and government, (3) a technical basis for equity in trade, and (4) technical services to promote public safety. The Bureau consists of the Institute for Basic Standards, the Institute for Materials Research, the Institute for Applied Technology, the Center for Computer Sciences and Technology, and the Office for Information Programs.

THE INSTITUTE FOR BASIC STANDARDS provides the central basis within the United States of a complete and consistent system of physical measurement; coordinates that system with measurement systems of other nations; and furnishes essential services leading to accurate and uniform physical measurements throughout the Nation's scientific community, industry, and commerce. The Institute consists of a Center for Radiation Research, an Office of Measurement Services and the following divisions:

Applied Mathematics-Electricity-Heat-Mechanics-Optical Physics-Linac Radiation ${ }^{2}-$ Nuclear Radiation ${ }^{2}-$ Applied Radiation $^{2}$-Quantum Electronics ${ }^{3}$ Electromagnetics ${ }^{3}$ - Time and Frequency ${ }^{3}-$ Laboratory Astrophysics ${ }^{3}-$ Cryogenics $^{3}$.

THE INSTITUTE FOR MATERIALS RESEARCH conducts materials research leading to improved methods of measurement, standards, and data on the properties of well-characterized materials needed by industry, commerce, educational institutions, and Government; provides advisory and research services to other Government agencies; and develops, produces, and distributes standard reference materials. The Institute consists of the Office of Standard Reference Materials and the following divisions:

Analytical Chemistry-Polymers-Metallurgy-Inorganic Materials-Reactor Radiation-Physical Chemistry.

THE INSTITUTE FOR APPLIED TECHNOLOGY provides technical services to promote the use of available technology and to facilitate technological innovation in industry and Government; cooperates with public and private organizations leading to the development of technological standards (including mandatory safety standards), codes and methods of test; and provides technical advice and services to Government agencies upon request. The Institute also monitors NBS engineering standards activities and provides liaison between NBS and national and international engineering standards bodies. The Institute consists of a Center for Building Technology and the following divisions and offices:

Engineering Standards Services-Weights and Measures-Invention and Innovation-Product Evaluation Technology-Electronic Technology-Technical Analysis-Measurement Engineering-Fire Technology-Housing Technology ${ }^{4}$ -Federal Building Technology ${ }^{4}$-Building Standards and Codes Services ${ }^{4}$ Building Environment ${ }^{4}$-Structures, Materials and Life Safety ${ }^{4}$-Technical Evaluation and Application 4 .

THE CENTER FOR COMPUTER SCIENCES AND TECHNOLOGY conducts research and provides technical services designed to aid Government agencies in improving cost effectiveness in the conduct of their programs through the selection, acquisition, and effective utilization of automatic data processing equipment; and serves as the principal focus within the executive branch for the development of Federal standards for automatic data processing equipment, techniques, and computer languages. The Center consists of the following offices and divisions:

Information Processing Standards-Computer Information-Computer Services -Systems Development-Information Processing Technology.

THE OFFICE FOR INFORMATION PROGRAMS promotes optimum dissemination and accessibility of scientific information generated within NBS and other agencies of the Federal Government; promotes the development of the National Standard Reference Data System and a system of information analysis centers dealing with the broader aspects of the National Measurement System; provides appropriate services to ensure that the NBS staff has optimum accessibility to the scientific information of the world, and directs the public information activities of the Bureau. The Office consists of the following organizational units:

Office of Standard Reference Data-Office of Technical Information and Publications-Library-Office of International Relations.

\footnotetext{
1 Headquarters and Laboratories at Gaithersburg, Maryland, unless otherwise noted; mailing address Washington, D.C. 20234.

${ }^{2}$ Part of the Center for Radiation Research.

3 Located at Boulder, Colorado 80302.

- Part of the Center for Buflding Technolog.
} 


\section{DISCLOSURES ON:}

\section{New Syntheses of Perfluorostyrene and}

972 Other Highly Fluorinated Derivatives

c. 2 Temperature-, Radiation-, and

\section{Mill Work Positioner}

Process for Fabricating Superconducting Microbridges

Apparatus for Displaying Average Wind Vane

or Other Shaft Position

Document Numbering Machine Responsive to a Staple in a Print Area for Printing in an Alternate Area

David Robbins and Alvin J. Englert, Editors

Patent Adviser's Office

National Bureau of Standards

Washington, D.C. 20234

NBS Technical Notes are designed to supplement the Bureau's regular publications program. They provide a means for making available scientific data that are of transient or limited interest. Technical Notes may be listed or referred to in the open literature.

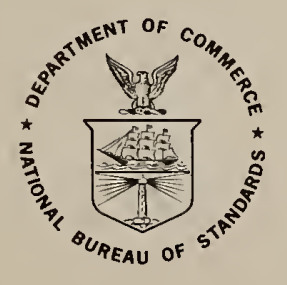

U.S. DEPARTMENT OF COMMERCE, Peter G. Peterson, Secrefary NATIONAL BUREAU OF STANDARDS, Lawrence M. Kushner, Acfing Director, Issued November 1972 


\section{National Bureau of Standards Technical Note 744}

Nat. Bur. Stand. (U.S.), Tech. Note 744, 31 pages (Nov. 1972)

CODEN: NBTNAE

For sale by the Superintendent of Documents, U.S. Government Printing Office, Washington, D.C. 20402 (Order by SD Catalog No. C13.46:744). Price 55 cents. 


\section{PREFACE}

This NBS Technical Note is one of a continuing series entitled "Disclosures on ...." This series consists of short descriptions of recent developments from the Department of Commerce primary operating units, departmental staff offices, and their contractors. It is believed that these developments have important commercial applications. Unless otherwise stated in the description of a development, the property rights therein have been retained by the United States as represented by the Secretary of Commerce.

Previous NBS Technical Notes in this series are NBS Technical Notes 237, 253, 263, 282, 287, 295, 437, 440 and 536 .

David Robbins

Patent Adviser 
CONTENTS

Title

Author(s)

$\underline{\text { Page }}$

New Syntheses of

L. A. Wall

Perfluorostyrene and Other

J. M. Antonucci

Highly Fluorinated

D. W. Brown

Derivatives

Temperature-, Radiation-, and Vacuum-Resistant

K. F. Plitt

Magnetic Tape

Conductometric Tițration Cell

Mill Work Positioner

J. M. Holloway

K. H. Gebert

L. 0. Mullen

Process for Fabricating

Superconducting Microbridges

Apparatus for Displaying Average Wind Vane or Other Shaft Position

Document Numbering Machine Responsive to a Staple in a Print Area for Printing

in an Alternate Area

R. L. Johnson

H. H. Crouser 


\section{ABSTRACT}

This Note describes and illustrates seven

developments that are believed to embody interesting and unusual solutions to current problems in their fields.

\section{KEY WORDS}

Conductometry; decoding matrix; fluoroolefins; integrator; magnetic sensing probe; magnetic tape; microbridge; numbering machine; perfluorostyrene; shaft position encoder; staple detector; superconducting; synthesis, chemical; titration; wind vane; work positioner. 

NEW SYNTHESES OF PERFLUOROSTYRENE AND OTHER HIGHLY FLUORINATED DERIVATIVES

L. A. Wa11, J. M. Antonucci and D. W. Brown

U. S. Pat. No. 2,874,197 to Dixon discloses that certain fluoroolefins are capable of reacting with organolithium compounds by an addition-elimination process that results in the formation of new fluoroolefins and lithium fluoride. The general reaction scheme is

$$
\mathrm{RLi}+\mathrm{CX}_{1} \mathrm{X}_{2}=\mathrm{CFY} \longrightarrow \mathrm{RCY}=\mathrm{CX}_{1} \mathrm{X}_{2}+\mathrm{LiF}
$$

where $\mathrm{X}_{1}$ and $\mathrm{X}_{2}$ are both electronegative atoms or groups and $\mathrm{Y}$ is $\mathrm{F}$ or a fluoroalkyl group.

The application of this method to the synthesis of perfluorostyrene by the reaction of perfluorophenylithium and a moderate excess of tetrafluoroethylene at low temperatures $\left(-80\right.$ to $\left.20^{\circ} \mathrm{C}\right)$ failed to yield any of the desired monomer. Instead a very complex mixture of solid products was isolated. It is anticipated that the desired monomer will be useful for the preparation of new thermally stable polymeric materials.

Careful analysis of all the chief products and reactants in a series of investigations enabled us, however, to develop a process capable of producing the desired monomer. By employing a very large excess of tetrafluoroethylene (threefold or greater) and controlled reaction times at low temperatures, it was possible to form perfluorostyrene in fair yields (10-20\%). The formation of perfluorostyrene and the other monomers by this reaction was followed most conveniently by gas-liquid chromatography. From these studies, it was found that the yield of monomer is quite time dependent, reaching a maximum at a certain reaction time and decreasing thereafter. As expected, the optimum reaction time varies with the temperature of the reaction and with the specific reaction mixture employed. 
The general scheme is

$$
\mathrm{C}_{6} \mathrm{~F}_{5} \mathrm{Li}+\mathrm{CF}_{2}=\mathrm{CFX} \longrightarrow \mathrm{C}_{6} \mathrm{~F}_{5} \mathrm{CF}=\mathrm{CFX}
$$

where $\mathrm{X}=\mathrm{F}, \mathrm{Cl} ; \mathrm{H}, \mathrm{CF}_{3}$

\section{Synthesis of Perfluorophenyllithium}

Direct Metallation. Pentafluoroiodobenzene in ether was lithiated at -20 to $0^{\circ} \mathrm{C}$ by use of a lithium dispersion in paraffin. The technique employed was essentially that used to lithiate conventional halobenzenes.

Exchange Reaction. Pentafluorobenzene in ether was treated with an organolithium reagent, such as methyllithium, at $-80^{\circ} \mathrm{C}$ to give the desired perfluorophenyllithium. The technique employed was essentially that reported by Tamborski et al., J. Org. Chem. 29, 2385 (1964).

\section{Synthesis of Perfluorostyrene}

One mole of perfluorophenyllithium in 15 liters of ether was prepared in a 30-liter steel bomb maintained at $-80^{\circ} \mathrm{C}$. To this was added carefully 15 moles of tetrafluoroethylene. The bomb was sealed and then agitated for 3 to 5 days at $-20^{\circ} \mathrm{C}$. The reaction mixture was treated as follows at the conclusion of the reaction: any unreacted perfluorophenyllithium was hydrolyzed, the unreacted tetrafluoroethylene was removed and collected. The ether solution was then worked up in the usual way to yield $20 \%$ perfluorostyrene, b.p. $122^{\circ} \mathrm{C}$.

The same technique also proved successful in the reaction of trifluoroethylene with perfluorophenyllithium to give $\beta$-hydroheptafluorostyrene. Other successful syntheses included the reaction of perfluorophenyllithium with chlorotrifluoroethylene and perfluoropropylene to give

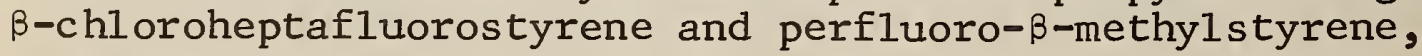
respectively. 
A related but somewhat different synthesis of perfluorostyrene was discovered in the course of these investigations and involves the dehydrofluorination of $\alpha$-hydrononafluoroethylbenzene (Wall et al. U. S. Pat. No. $3,265,746)$ with methyllithium at $-80^{\circ} \mathrm{C}$, followed by warming to $25^{\circ} \mathrm{C}$. The reaction sequence is believed to be

$$
\begin{aligned}
\mathrm{C}_{6} \mathrm{~F}_{5} \mathrm{CFHCF}_{3} & \underset{3}{\left(-\mathrm{CH}_{4}\right)} \\
& \frac{\mathrm{CH}_{3} \mathrm{Li}}{\text { ether }}>0^{\circ \mathrm{C}}
\end{aligned}
$$

Yields of perfluorostyrene of the order of 85 to $90 \%$ can be realized by this method. 
TEMPERATURE-, RADIATION-, AND VACUUM-RESISTANT MAGNETIC TAPE K. F. Plitt

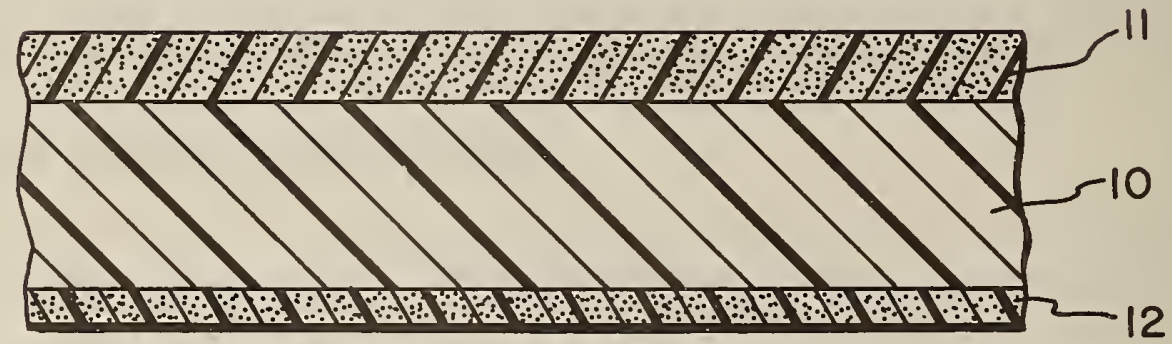


TEMPERATURE-, RADIATION-, AND VACUUM-RESISTANT MAGNETIC TAPE K. F. Plitt

Satellite tape recorders frequently fail because the magnetic tape sticks to a head surface. This is apparently due to the transfer of material from the tape to the head surface until that surface adheres easily to the tape.

In addition to a tape that will not contaminate head surfaces, a satellite recorder requires a magnetic tape that does not change properties when exposed to hard vacuum and has a high resistance to radiation. Further, for some applications, the tape should be capable of operating properly after sterilization by gaseous chemicals or by heating for 24 hours at $140^{\circ} \mathrm{C}$.

The tape described in this note meets these requirements. It consists of a base film 10 coated on each side with a different coating. The base film is a polyimide material chosen for its stability, temperature resistance, mechanical properties, and freedom from liquid plasticizers and volatile constituents. The coating 11 on the front side of the base film consists of a binder, magnetic iron oxide, and conductive carbon. It is applied from solution, dried, and cured. Suitable binders are polyimide resins and polyamide-imide resins. Other materials that may be used include high temperature resistant polymers such as polybenzimidazoles and pyrrones. The coating 12 on the back side of the base consists of a binder, preferably the same polymer used in the coating on the front side, conductive carbon, and in some cases powdered polytetrafluoroethylene. Coating 12 reduces cupping of tape during curing and provides lubrication for tapes that are to be used in "endless-loop" tape recorders. 
CONDUCTOMETRIC TITRATION CELL

T. B. Hoover

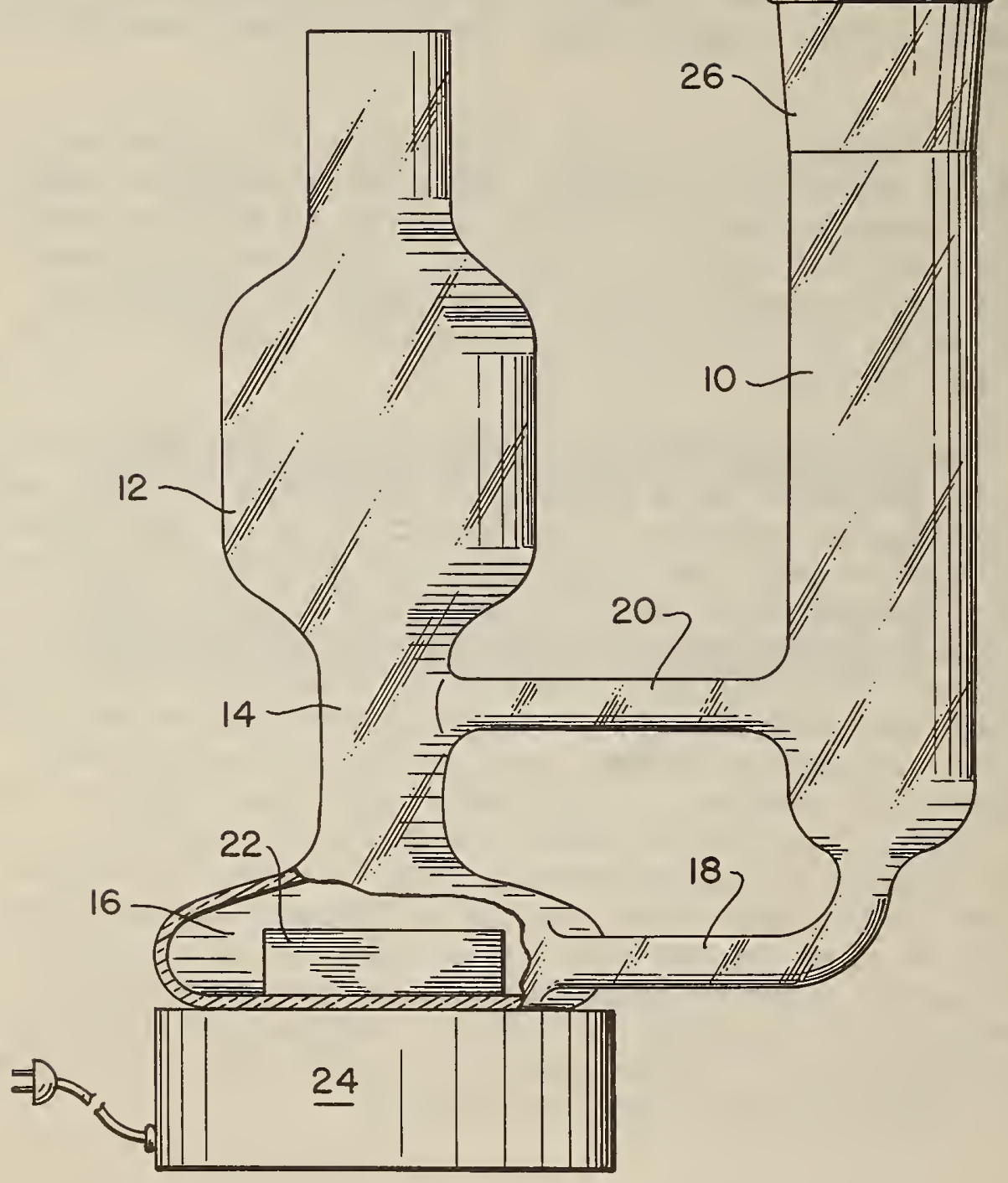


T. B. Hoover

Ten microequivalents or less of a specimen dissolved in 25-50 $\mathrm{ml}$ of solvent can be titrated using this cell. The titration, which may be performed in an inert atmosphere, is monitored by measuring the solution conductivity as the reagent is added. The solution is stirred magnetically and the electrodes are positioned away from the stirrer to avoid current induction by the rotating magnetic field.

As shown in the figure, the cell consists of an electrode chamber 10 and a flask 12 with a neck 14 and a stirring chamber 16. A feed arm 18 extending tangentially from the stirring chamber 16 is connected to the bottom of the electrode chamber 10 and a return arm 20 is connected to the flask neck 14. A magnetic stirring bar 22 introduced into the stirring chamber 16 through the neck 14 is driven by a rotating magnet drive 24 . The solution is thus centrifugally stirred and circulated through the cell. The electrode circuit or "loop" (not shown), being outside the fringing stirrer field, avoids the induction of extraneous currents.

The electrode chamber top has a standard taper joint 26 for receiving interchangeable dipping electrodes of different cell constants appropriate to the solvent-reagent system used. The flask 12 may be provided with a serum cap (not shown) through which the titrant and a purge or filling gas for controlling the cell atmosphere may be introduced by hypodermic needles. 
J. M. Holloway and K. H. Gebert milling machine.

This device may be used to position work on a

In the figures bolt 10 passes through post 11. Machine nut 12 is threaded on one end of the bolt and T-nut 13 is threaded on the other end. Stop rod 14 is made off set and has one end located in one of the holes 15 in the post. Instead of 14, two straight arms and a swivel clamp may be used. When this arrangement is used, one of the arms is located in a fixed position between the clamp and post 11, while the other arm is located in the clamp. By proper adjustment of the clamp, an end of the second arm may be moved horizontally, vertically, or along a desired angle.

In a typical operation, $T$-nut 13 is positioned in a slot in the table of the milling machine. The T-nut is tightened. A piece of work is placed in a vise on the table. Stop rod 14 is then positioned in the hole in post 11, corresponding to the height of the work, and the rod is rotated to make fine adjustments in height, if required, before it is clamped by the related screw 16 . The piece of work is then moved horizontally in the vise to engage the end of stop rod 14 and is thereby positioned precisely on the milling machine. 
MILL WORK POSITIONER

J. M. Holloway and K. H. Gebert
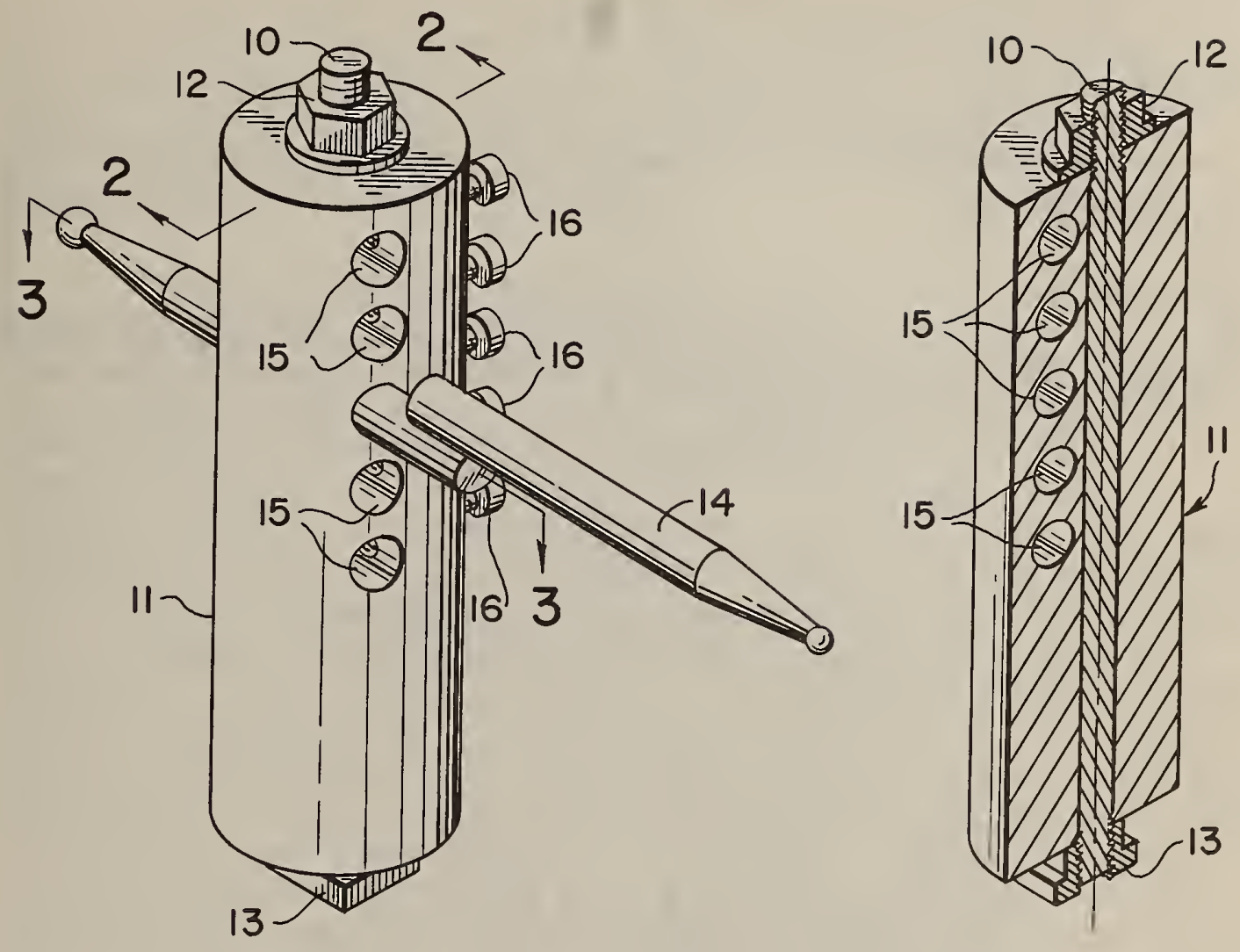

FIG.I

FIG. 2

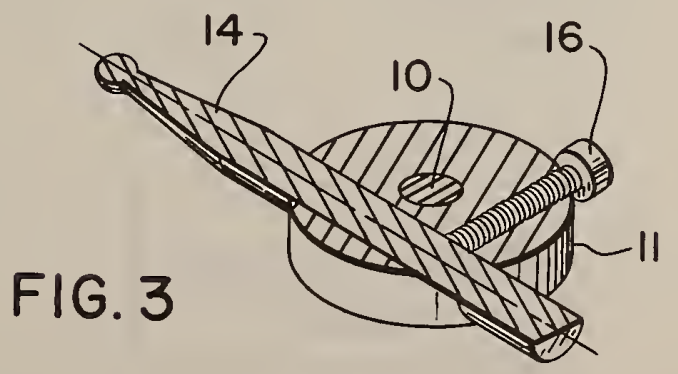


PROCESS FOR FABRICATING SUPERCONDUCTING MICROBRIDGES

L. 0. Mullen

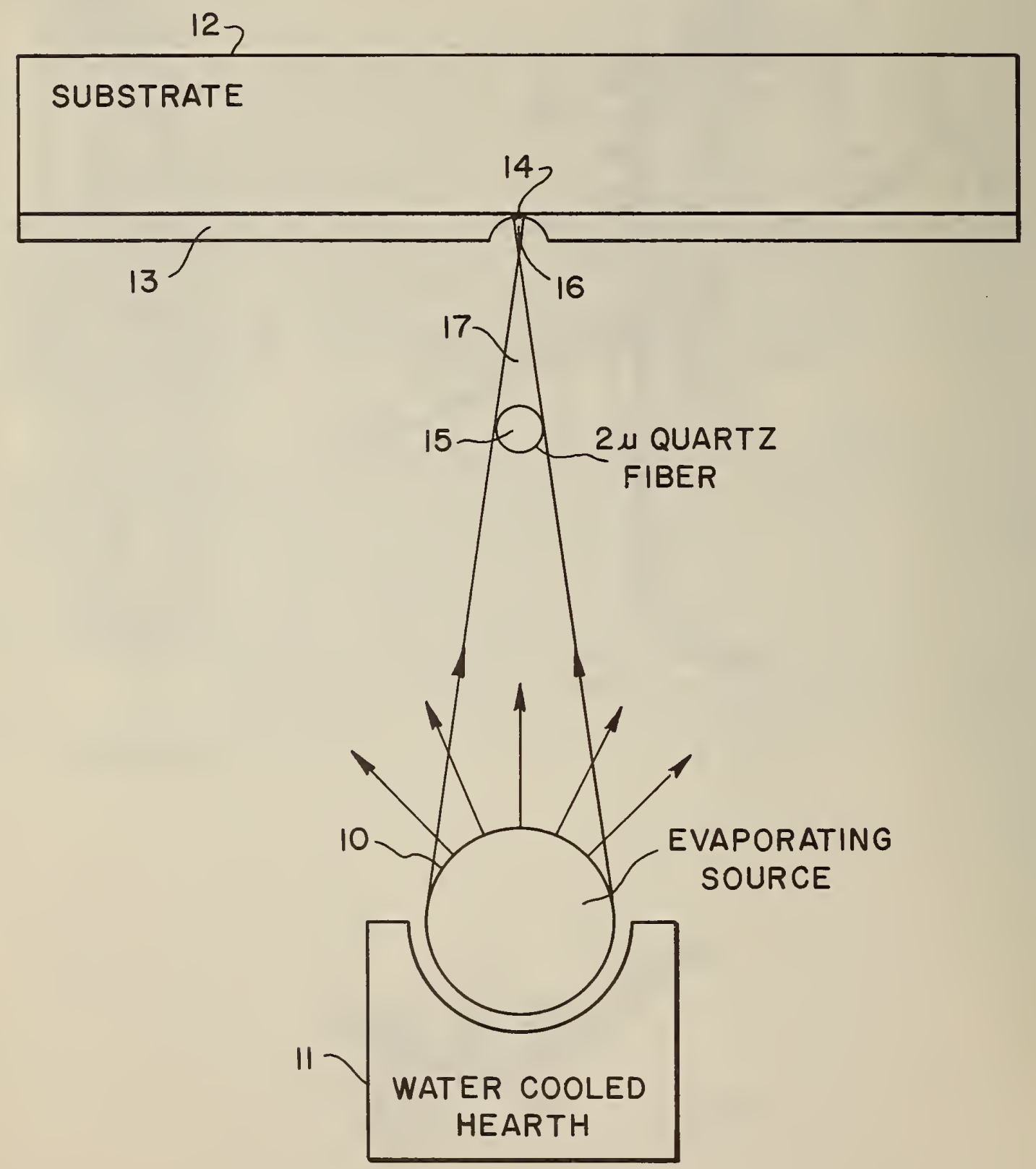


PROCESS FOR FABRICATING SUPERCONDUCTING MICROBRIDGES

L. 0. Mullen

The essence of a superconducting microbridge is a controlled constriction of a strip of superconducting thin film where the conductivity is weakened in a well-defined area. This note describes a process for precisely controlling the width and thickness of the film in the constriction or metallic bridge.

The structure shown in the figure is positioned in a suitable vacuum. An evaporating source 10 comprises a ball of superconducting material, such as niobium, and is placed in a water cooled hearth 11 . The source is heated by a conventional electron beam arrangement, not shown, to between $3100^{\circ} \mathrm{K}$ to $3500^{\circ} \mathrm{K}$. Some of the molecules, evaporated from the source, travel in a straight line toward substrate 12, which is preferably sapphire for niobium, and a thin film 13 is deposited on the surface of the substrate. The thickness and width of the film deposited along a selected line to form a metallic bridge 14 is controlled by properly positioning a thin quartz fiber 15. (The fiber may be 2 microns thick.) More specifically, the width and thickness of the bridge are controlled by the penumbra 16 of the shadow 17 produced by the fiber. The width and thickness of the penumbra are in turn controlled by the diameter and position of the fiber 15 from substrate 12 . The thickness of the bridge also depends upon the time and rate of deposition of the film. 
APPARATUS FOR DISPLAYING AVERAGE WIND VANE OR OTHER SHAFT POSITION

H. H. Crouser

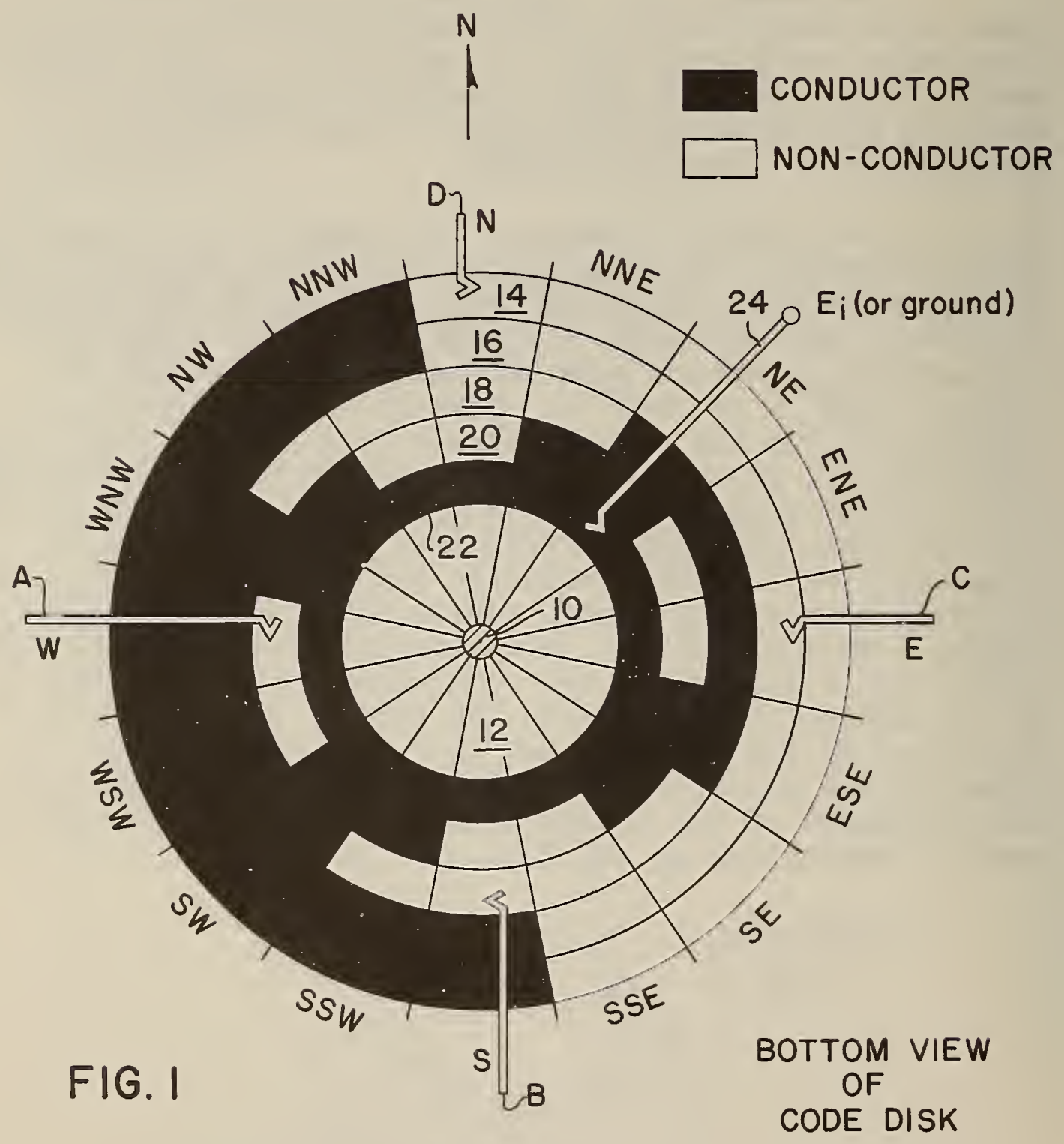


APPARATUS FOR DISPLAYING AVERAGE WIND VANE OR OTHER SHAFT POSITION

H. H. Crouser

This device encodes instantaneous shaft position in a cyclic bit code having equal on-and-off distributions and time integrates each bit. If the integral exceeds a threshold, the bit is fed to a code converter which drives a display unit. The device is particularly useful in reporting average wind directions from a remote batterypowered weather station.

As shown in Fig. 1 the fluctuating wind vane or other shaft 10 is equipped with a cyclic code disk 12 . The first and second outer rings 14 and 16 of the disk each have a $180^{\circ}$ arcuate metal segment. The third ring 18 has two evenly spaced $90^{\circ}$ segments and the fourth ring 20 has four $45^{\circ}$ segments. For greater shaft position resolution there could be provided a fifth ring with eight $22.5^{\circ}$ segments, and so on. The continuous inner band 22 is the common circuit terminal energized with voltage $E_{i}$ from brush 24 . The voltage is picked up from the rings $14^{i}, 16,18$ and 20 by brushes D, C, B and A respectively. For ease of construction these brushes are positioned at $90^{\circ}$ intervals around the disk 12. The resulting cyclic code of the sixteen wind directions is as follows.

$\begin{array}{llll}\text { N } & 0000 & \text { S } & 0011 \\ \text { N NE } & 1000 & \text { S SW } & 1011 \\ \text { NE } & 1100 & \text { SW } & 1111 \\ \text { E NE } & 0100 & \text { W SW } & 0111 \\ \text { E } & 0110 & \text { W } & 0101 \\ \text { E SE } & 1110 & \text { W NW } & 1101 \\ \text { SE } & 1010 & \text { NW } & 1001 \\ \text { S SE } & 0010 & \text { N NW } & 0001\end{array}$


APPARATUS FOR DISPLAYING AVERAGE WIND VANE OR OTHER SHAFT POSITION

H. H. Crouser

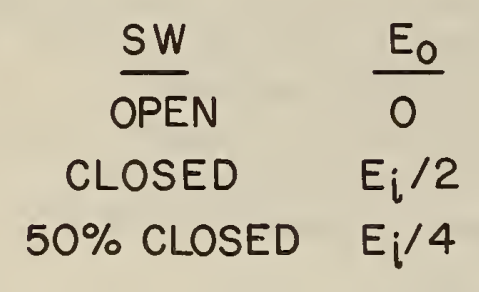

FIG. 2

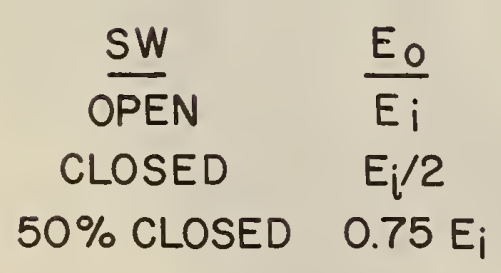

FIG. 4
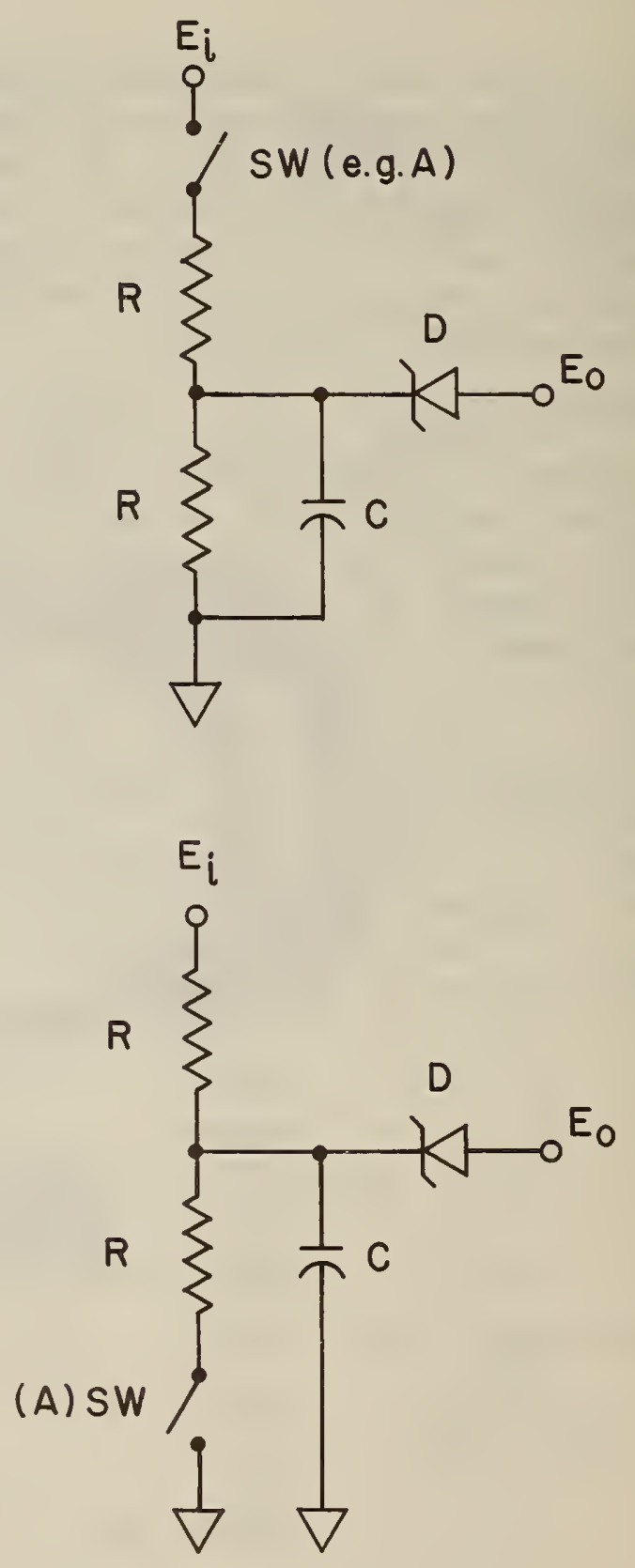
The circuit for integrating (smoothing) the individual encoder output bits is shown in Fig. 2. The voltage $E_{i}$ picked up by a brush such as $A$ (shown as a switch arm) is applied across two equal resistors. A capacitor is connected across the lower resistor and a zener diode is back connected to the junction of the resistors. The resistor values preferably are high to limit the current drain from the source $E_{i}$ and the capacitance value is selected to provide the ${ }^{i}$ desired averaging time constant. If the brush contact time exceeds $50 \%$ the voltage across the capacitor generally will be between $E_{i} / 4$ and $E_{i} / 2$. The zener diode therefore is selected to conduct at slightly more than $E_{i} / 4$, providing the output bit " 1 ".

The four outputs, A to $D$, may be connected to a conventional decoding matrix with 16 output lines for displaying the 16 compass point wind directions. The top half of Fig. 3 shows the first three lines of such a matrix. The bottom half of Fig. 3 shows an alternative matrix which provides 8 overlapping wind directions. Here the direction NNE is indicated by the simultaneous energization of the lines "N" and "NE".

To prevent damage to the power supply, brushes, or code disk in the event one of the brushes $A$ to $D$ is accidentally shorted to ground, the common voltage applied to the inner disk ring 22 may be ground rather than the supply voltage $E_{i}$. Fig. 4 shows the smoothing circuit in this case. The output bit " 1 " is produced when the brush circuit closure time is less than $50 \%$. This causes an inversion of the cyclic code, with a corresponding change in the decoding matrices, shown in Fig. 5. Also the zener diode is selected to conduct at slightly more than $0.75 \mathrm{E}_{i}$.

Under some weather service conditions it may be desirable to display the average wind direction in a 36point format. A cyclic code having equal on-and-off distributions for this purpose is as follows. 


$\begin{array}{cccc}\text { DIR. } & \text { CODE } & \text { DIR. } & \text { CODE } \\ 36 & 000000 & 18 & 001111 \\ 01 & 100000 & 19 & 101111 \\ 02 & 110000 & 20 & 11111 \\ 03 & 111000 & 21 & 110111 \\ 04 & 011000 & 22 & 010111 \\ 05 & 001000 & 23 & 000111 \\ 06 & 001100 & 24 & 000011 \\ 07 & 101100 & 25 & 100011 \\ 08 & 111100 & 26 & 110011 \\ 09 & 110100 & 27 & 111011 \\ 10 & 010100 & 28 & 011011 \\ 11 & 000100 & 29 & 001011 \\ 12 & 000110 & 30 & 001001 \\ 13 & 100110 & 31 & 101001 \\ 14 & 110110 & 32 & 111001 \\ 15 & 111110 & 33 & 110001 \\ 16 & 011110 & 34 & 010001 \\ 17 & 001110 & 35 & 000001\end{array}$


APPARATUS FOR DISPLAYING AVERAGE WIND VANE OR OTHER SHAFT POSITION

H. H. Crouser

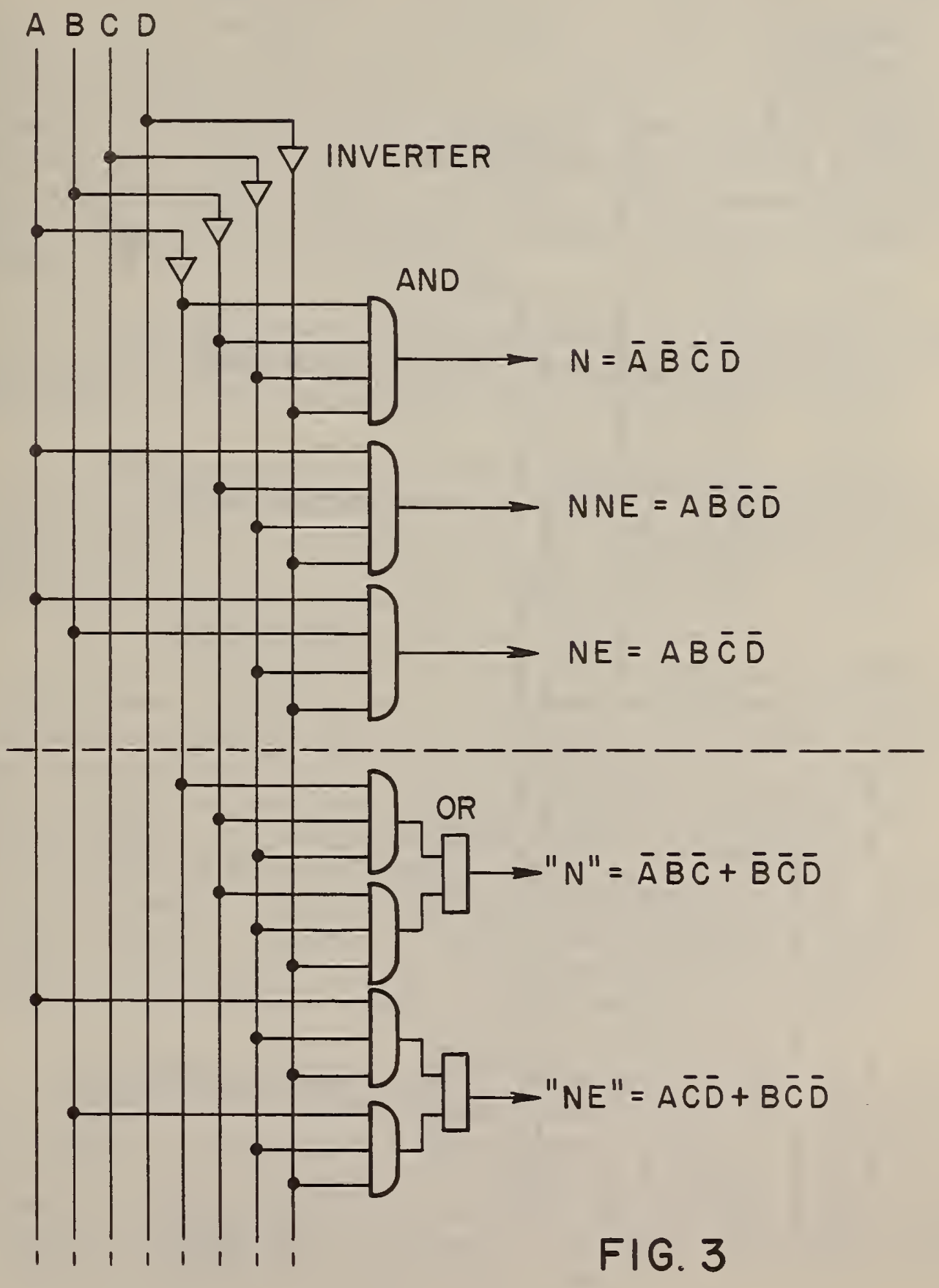


APPARATUS FOR DISPLAYING AVERAGE WIND VANE OR OTHER SHAFT POSITION

H. H. Crouser

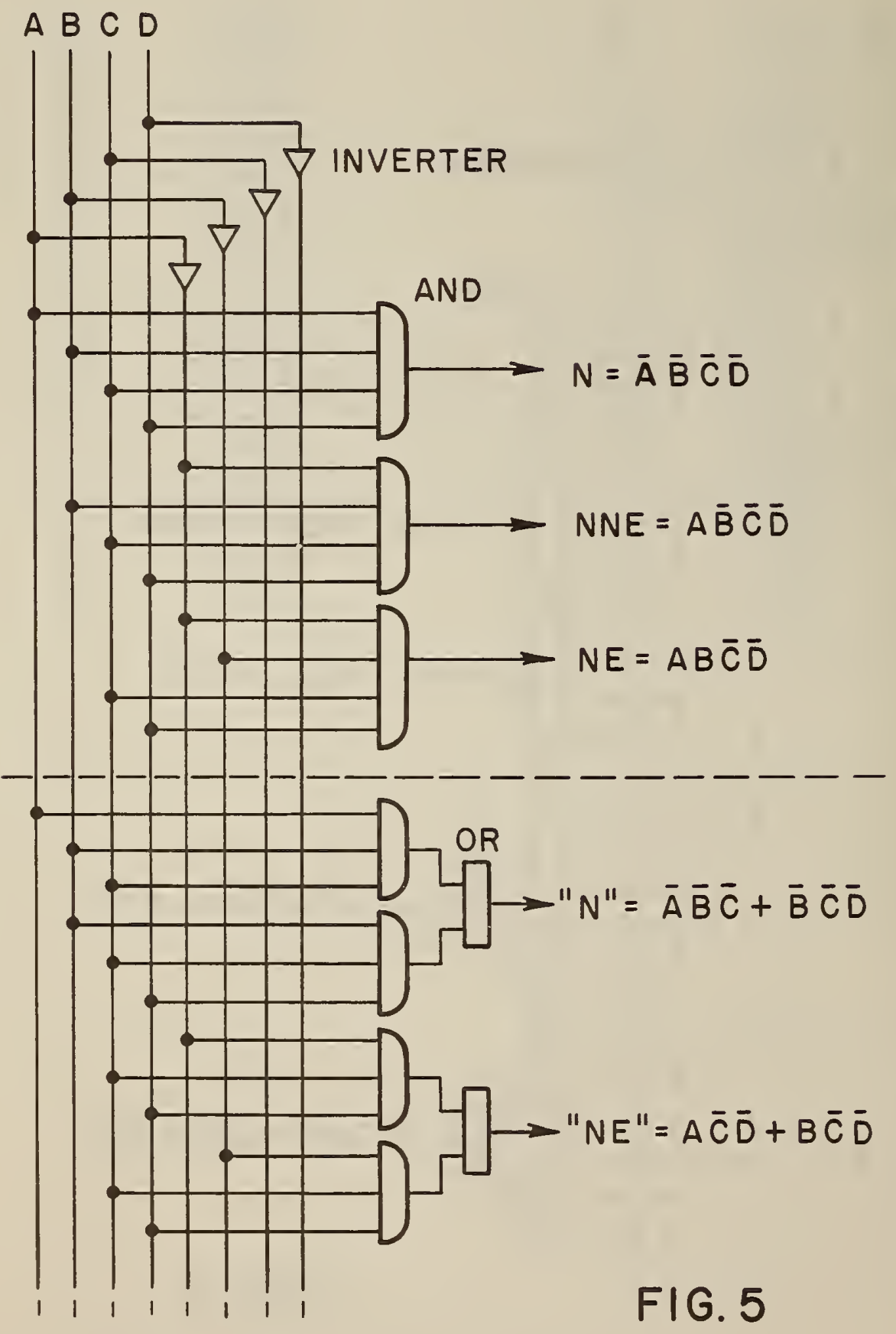


DOCUMENT NUMBERING MACHINE RESPONSIVE TO A STAPLE IN A PRINT AREA FOR PRINTING IN AN ALTERNATE AREA

R. J. Varson and R. L. Johnson

In processing a multi-element separable document such as a tax return, it is common to print a document locator number (DLN) on all the elements to facilitate their location after the document is separated. The DLN can be automatically printed by a document feeding and numbering machine, provided the document does not contain a staple in the assigned print area. A staple will damage the print wheels, result in an illegible number, or cause an erroneous advance of the print wheels.

The purpose of this apparatus is to sense a staple in the print area of a document and delay the printing of the number so that it appears in an alternate area.

The apparatus is shown schematically in Fig. 1. It includes an inductive staple sensing probe (SP) 1 which is mounted ahead of the printer 24 in the document feed path. The sensing probe 1 drives a loaded oscillator (OSC) 2 which in turn strobes an AND circuit 4.

As a document is fed into the machine it interrupts a light beam impinging on a photocell (PC) 12, causing the photocell amplifier (PA) 13 to produce an output as long as the document is passing over the photocell 12. The leading edge of this output pulse is delayed by a delayed make circuit (DM) 14. The amount of delay is adjustable by the operator and serves to adjust the position of the first print on the document. The output of the delayed make circuit 14 is also used to trigger a pulse width control circuit (PWC) 3 which establishes a zone to be tested for staples by providing an enable to AND circuit 4.

If the sensing probe 1 detects a staple and therefore strobes AND circuit 4 while the latter is enabled by the output of the pulse width control circuit 3, the strobe signal will pass through and initiate a pulse width control curcuit 5. This circuit 5 expands the staple pulse so that a staple detected at any time in the test zone will appear to exist during the entire test zone. 
DOCUMENT NUMBERING MACHINE RESPONSIVE TO A STAPLE IN A PRINT AREA FOR PRINTING IN AN ALTERNATE AREA

R. J. Varson and R. L. Johnson

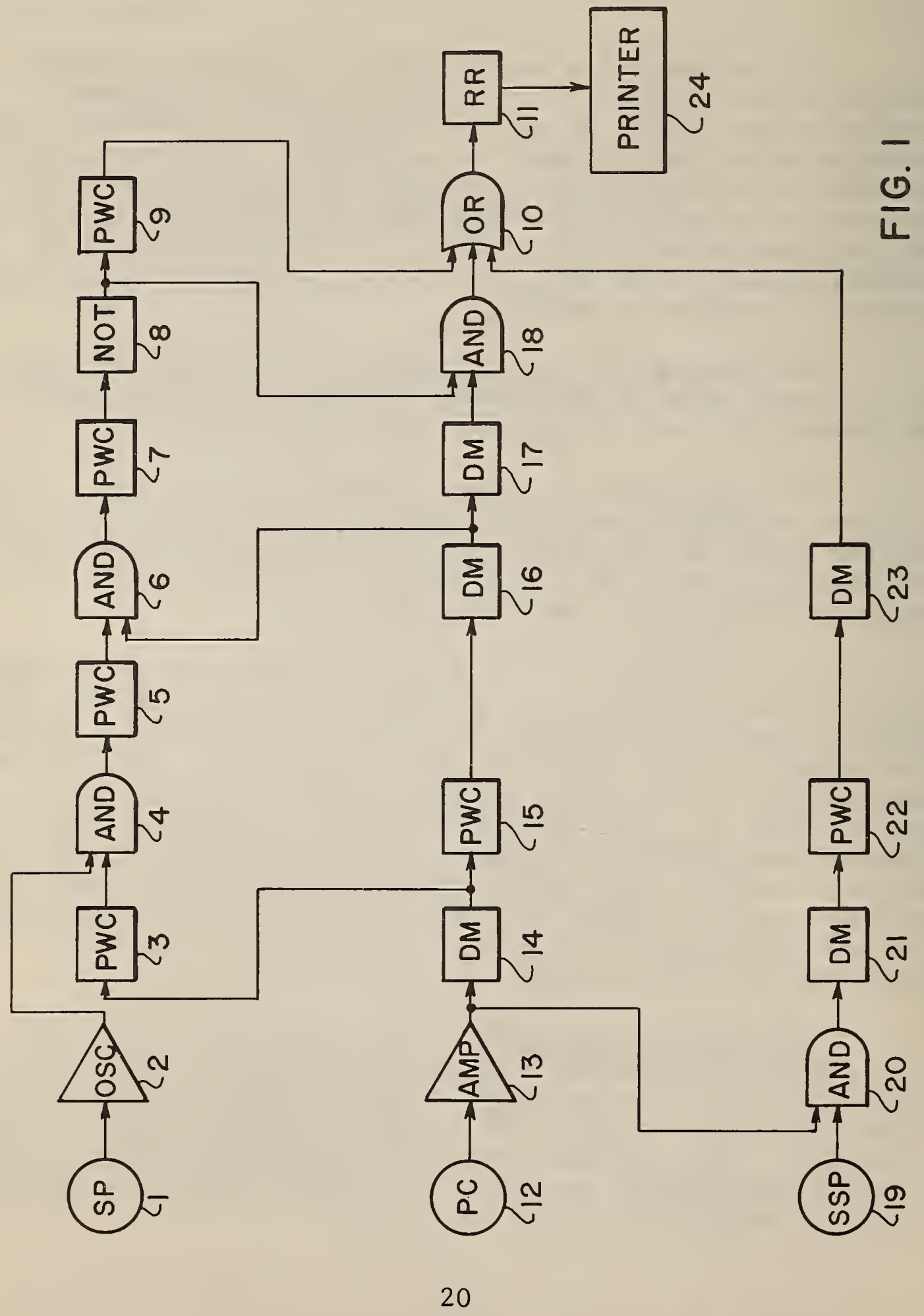


The previously mentioned delayed make circuit 14 identified the location of the first print relative to the sense probe 1 . Its output is applied to a pulse width control circuit 15 where it is extended beyond the first print location at the print head. The output of this pulse width control circuit 15 triggers a delayed make circuit 16 which delays it almost to the first print. Pulse 16 enables an AND circuit 6 at a time relative to the top of the document so that pulse 6 will not vary with the location of the staple. Pulse 6 triggers a pulse width control circuit 7 which is operator adjusted to set the alternate print location ("staple detected in first print location"). Pulse 7 is applied to an inverting circuit (NOT) 8. The restoration of pulse 8 at the trailing edge of pulse 7 triggers a pulse width control circuit 9 to produce a short pulse which passes through an OR gate 10 to operate a reed relay $(R R)$ 11. The OR gate 10 is needed so that the reed relay 11 can be operated from more than one source to trigger the print circuits in printer 24.

If no staple pulse 1 occurred to coincide with enable 3 then circuits 4 through 9 as described above will remain inactive and pulse 16 will initiate a delayed make circuit 17 which delays it to approximately the middle of the test zone. Pulse 17 strobes an AND circuit 18 which is enabled by NOT circuit 8 if the alternate print logic was not activated by a staple. Pulse 18 passes through OR gate 10 to operate the reed relay 11 for a normal first print.

Should a second print be desired, a "select second print" circuit 19 enables an AND gate 20 allowing the photocel1 12 to initiate a delayed make circuit 21. This circuit 21 is operator adjustable and delays the pulse to set the second print location and start a pulse width control circuit 22 which extends it beyond the second print location and triggers a delayed make circuit 23. This circuit 23 delays the leading edge to produce the print pulse. Pulse 23 passes through OR gate 10 and operates the reed relay 11 to trigger the printer 24 .

Figs. 2 and 3 show two examples of the pulses produced by the circuits for documents of different sizes with staples in and after the test zone. The conditions for Fig. 2 are: 
Minimum Page Length - Close Spaced

Minimum Delay First Print

Minimum Delay Second Print

First Document - Staple in Test Zone

Second Document - Staple after Test Zone

For Fig. 3 the conditions are:

Five Inch Page Length - Wide Spaced

First Print $\frac{1}{4}$ Inch Below Top

Alternate Print One Inch After First

Second Print $\frac{1}{2}$ Inch from Bottom

First Document - Staple Early in Test Zone

Second Document - Staple Middle of Test Zone

The above-described apparatus is designed to print near the top of the document. Since staples are seldom encountered in other areas, the staple detection is applied only to the first print. However, the staple detection could be applied to the second print if desired. Also, the number of prints per document could be expanded. 
DOCUMENT NUMBERING MACHINE RESPONSIVE TO A STAPLE IN A PRINT AREA FOR PRINTING IN AN ALTERNATE AREA

\section{R. J. Varson and R. L. Johnson}

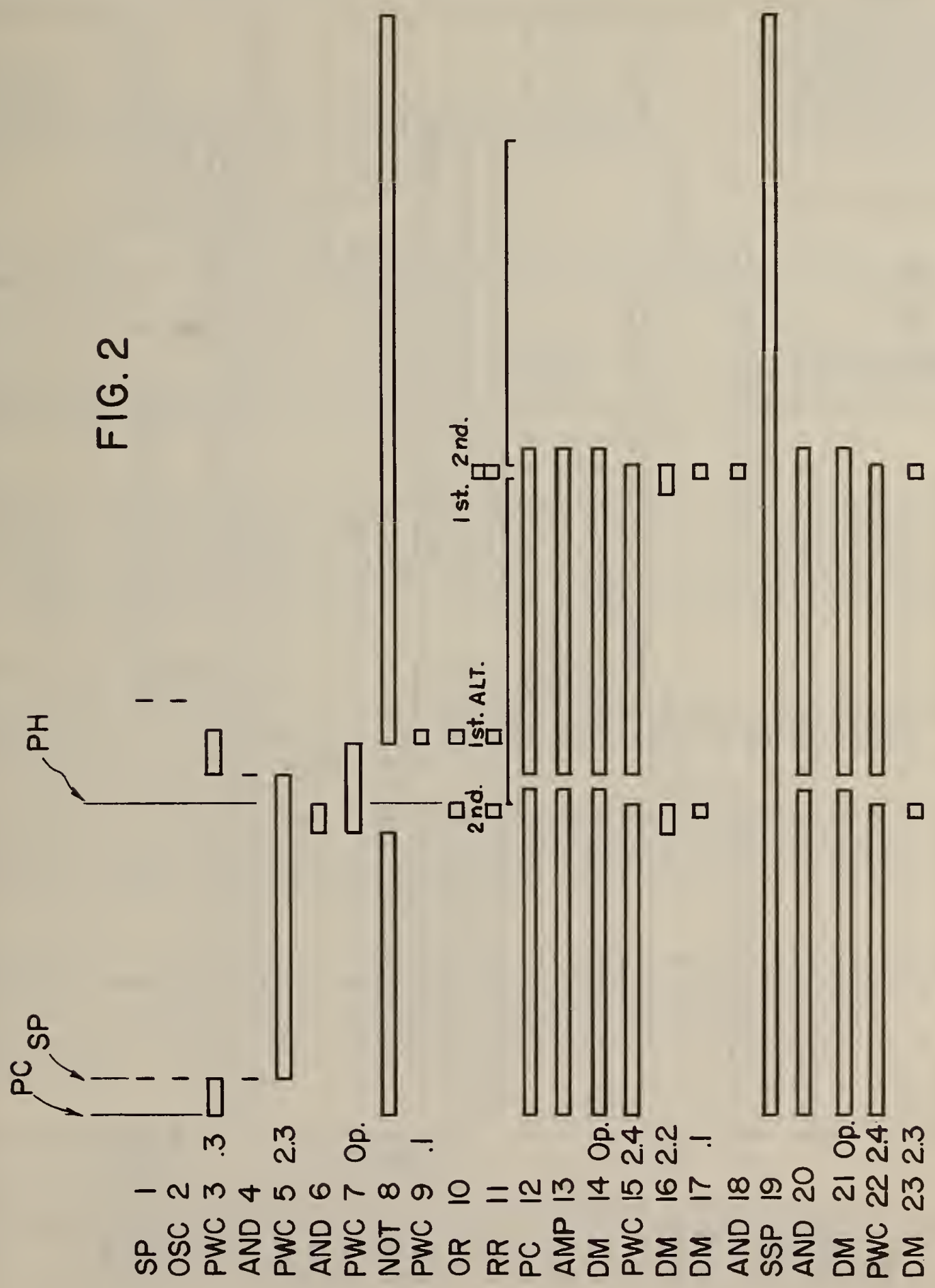


DOCUMENT NUMBERING MACHINE RESPONSIVE TO A STAPLE IN A PRINT AREA FOR PRINTING IN AN ALTERNATE AREA

R. J. Varson and R. L. Johnson

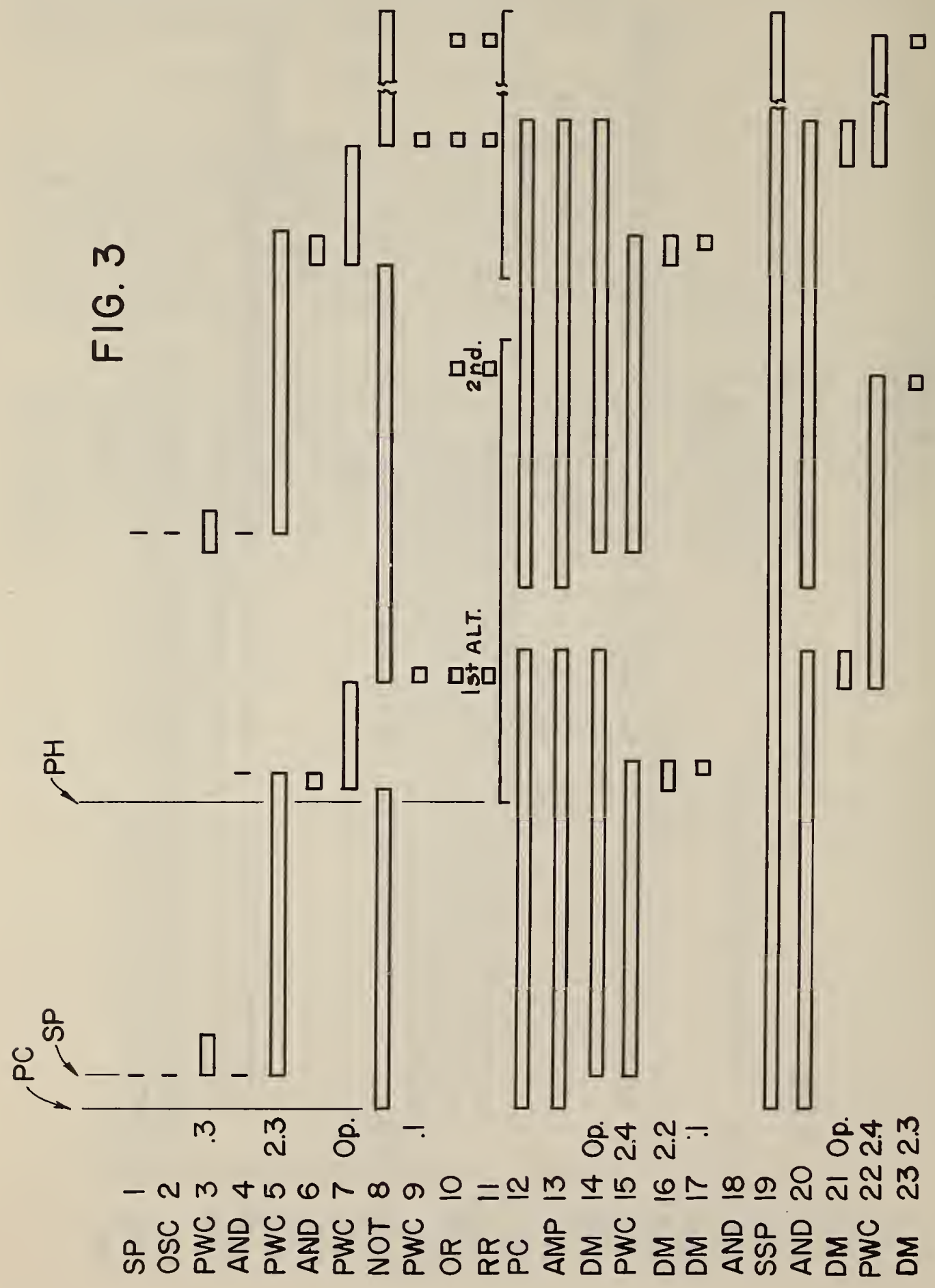


FORM NBS-114A (1.71)

\begin{tabular}{|c|c|c|c|}
\hline $\begin{array}{l}\text { U.S. DEPT. OF COMM. } \\
\text { BIBLIOGRAPHIC DATA } \\
\text { SHEET }\end{array}$ & $\begin{array}{l}\text { 1. PUBLICATION OR REPORT NO. } \\
\qquad \text { NBS TN }-744\end{array}$ & $\begin{array}{l}\text { 2. Gov't Accession } \\
\text { No. }\end{array}$ & 3. Recipient's Accession No. \\
\hline \multicolumn{3}{|l|}{ 4. TIT LE AND SUBTITLE } & $\begin{array}{l}\text { 5. Publication Date } \\
\text { November } 1972\end{array}$ \\
\hline Disclosures on: & \multicolumn{2}{|c|}{ in item 16] } & 6. Performing Organization Code \\
\hline \multicolumn{2}{|c|}{ 7. AUTHOR(S) } & itors & 8. Performing Organization \\
\hline \multicolumn{3}{|c|}{ 9. PERF ORMING ORGANIZATION NAME AND ADDRESS } & 10. Project/Task/Work Unit No. \\
\hline \multicolumn{2}{|c|}{$\begin{array}{l}\text { NATIONAL BUREAU OF STAND ARDS } \\
\text { DEPARTMENT OF COMMERCE } \\
\text { WASHINGTON, D.C. } 20234\end{array}$} & & 11. Contract/Grant No. \\
\hline \multirow[t]{2}{*}{ Same as } & \multirow[t]{2}{*}{ item 9.} & & $\begin{array}{l}\text { 13. Type of Report \& Period } \\
\text { Covered } \\
\text { Final }\end{array}$ \\
\hline & & & 14. Sponsoring A gency Code \\
\hline
\end{tabular}

15. SUPPLEMENT ARY NOTES

16. ABSTRACT (A 200-word or less factual summary of most significant information. If document includes a significant bibliography or literature survey, mention it here.)

This Note describes and illustrates seven developments that are believed to embody interesting and unusual solutions to current problems in their fields.

Disclosure titles:

New Syntheses of Perfluorostyrene and Other Highly Fluorinated Derivatives Temperature-, Radiation-, and Vacuum-Resistant Magnetic Tape Conductometric Titration Cell

Mill Work Positioner

Process for Fabricating Superconducting Microbridges

Apparatus for Displaying Average Wind Vane or Other Shaft Position

Document Numbering Machine Responsive to a Staple in a Print Area

for Printing in an Alternate Area

KEY WORDS: Conductometry; decoding matrix; fluoroolefins; integrator; magnetic sensing probe; magnetic tape; microbridge; numbering machine; perfluorostyrene; shaft position encoder; staple detector; superconducting; synthesis, chemical; titration; wind vane; work positioner.

17. KEY WORDS (Alphabetical order, separated by semicolons)

See No. 16.

18. AVAILABILITY STATEMENT

X. UNL IMIT ED.

FOR OFFICIAL DISTRIBUTION. DO NOT RELEASE TO NTIS.

\begin{tabular}{|c|c|}
\hline $\begin{array}{c}\text { 19. SECURITY CLASS } \\
\text { (THIS REPORT) }\end{array}$ & 21. NO. OF PAGES \\
UNCL ASSIFIED & 31 \\
\hline $\begin{array}{c}\text { 20. SECURITY CLASS } \\
\text { (THIS PAGE) }\end{array}$ & 22. Price \\
UNCL ASSIFIED & 55 cents \\
\hline
\end{tabular}





\section{NBS TECHNICAL PUBLICATIONS}

PERIODICALS

JOURNAL OF RESEARCH reports National Bureau of Standards research and development in physics, mathematics, and chemistry. Comprehensive scientific papers give complete details of the work, including laboratory data, experimental procedures, and theoretical and mathematical analyses. Illustrated with photographs, drawings, and charts. Includes listings of other NBS papers as issued.

Published in two sections, available separately:

\section{- Physics and Chemistry}

Papers of interest primarily to scientists working in these fields. This section covers a broad range of physical and chemical research, with major emphasis on standards of physical measurement, fundamental constants, and properties of matter. Issued six times a year. Annual subscription: Domestic, $\$ 9.50 ; \$ 2.25$ additional for foreign mailing.

\section{- Mathematical Sciences}

Studies and compilations designed mainly for the mathematician and theoretical physicist. Topics in mathematical statistics, theory of experiment design, numerical analysis, theoretical physics and chemistry, logical design and programming of computers and computer systems. Short numerical tables. Issued quarterly. Annual subscription: Domestic, $\$ 5.00$; $\$ 1.25$ additional for foreign mailing.

\section{TECHNICAL NEWS BULLETIN}

The best single source of information concerning the Bureau's measurement, research, developmental, cooperative, and publication activities, this monthly publication is designed for the industry-oriented individual whose daily work involves intimate contact with science and technology-for engineers, chemists, physicists, research managers, product-development managers, and company executives. Includes listing of all NBS papers as issued. Annual subscription: Domestic, $\$ 3.00 ; \$ 1.00$ additional for foreign mailing.

\section{Bibliographic Subscription Services}

The following current-awareness and literaturesurvey bibliographies are issued periodically by the Bureau: Cryogenic Data Center Current Awareness Service (weekly), Liquefied Natural Gas (quarterly), Superconducting Devices and Materials (quarterly), and Electromagnetic Metrology Current Awareness Service (monthly). Available only from NBS Boulder Laboratories. Ordering and cost information may be obtained from the Program Information Office, NationaI Bureau of Standards, Boulder, Colorado 80302 .
MOKPERIODICALS

Applied Mathematics Series. Mathematical tables, manuals, and studies.

Building Science Series. Research results, test methods, and performance criteria of building materials, components, systems, and structures.

Handbooks. Recommended codes of engineering and industrial practice (including safety codes) developed in cooperation with interested industries, professional organizations, and regulatory bodies.

Special Publications. Proceedings of NBS conferences, bibliographies, annual reports, wall charts, pamphlets, etc.

Monographs. Major contributions to the technical literature on various subjects related to the Bureau's scientific and technical activities.

National Standard Reference Data Series. NSRDS provides quantitative data on the physical and chemical properties of materials, compiled from the world's literature and critically evaluated.

Product Standards. Provide requirements for sizes, types, quality, and methods for testing various industrial products. These standards are developed cooperatively with interested Government and industry groups and provide the basis for common understanding of product characteristics for both buyers and sellers. Their use is voluntary.

Technical Notes. This series consists of communications and reports (covering both other-agency and NBS-sponsored work) of limited or transitory interest.

Federal Information Processing Standards Publications. This series is the official publication within the Federal Government for information on standards adopted and promulgated under the Public Law 89-306, and Bureau of the Budget Circular A-86 entitled, Standardization of Data Elements and Codes in Data Systems.

Consumer Information Series. Practical information, based on NBS research and experience, covering areas of interest to the consumer. Easily understandable language and illustrations provide useful background knowledge for shopping in today's technological marketplace.

\section{CATALOGS OF NBS PUBLICATIOHS}

NBS Special Publication 305, Publications of the NBS. 1966-1967. When ordering, include Catalog No. C13.10:305. Price $\$ 2.00 ; 50$ cents additional for foreign mailing.

NBS Special Publication 305, Supplement 1, Publications of the NBS, 1968-1969. When ordering, include Catalog No. C13.10:305/Suppl. 1. Price $\$ 4.50 ; \$ 1.25$ additional for foreign mailing.

NBS Special Publication 305, Supplement 2, Publications of the NBS, 1970. When ordering, include Catalog No. C13.10:305/Suppl. 2. Price $\$ 3.25$; 85 cents additional for foreign mailing. 
U.S. DEPARTMENT OF COMMERCE National Bureau of Standards Washington, O.C. 20234

POSTAGE ANO FEES PAIO

OFFICIAL BUSINESS U.S. DEPARTMENT OF COMMERCE 215

Penalty for Privata Use, $\$ 300$ 